\title{
Los orígenes de la crisis de 1541-1543 en la política indiana de la monarquía
}

Antonio Acosta

Universidad de Sevilla

El autor arranca del hecho de que la historiografía sobre historia del comercio con las Indias en el siglo XVI, y sobre la encomienda, han avanzado en paralelo sin tomar en consideración la relación histórica existente entre ambas realidades. De ahí se señalan contradicciones económicas surgidas en dicha relación en la primera mitad de dicho siglo, hasta confluir en la crisis política de 1541-1543.

PALABRAS ClaVE: Comercio, encomienda, consulado, leyes nuevas, siglo XVI.

The author starts from the fact that the historiography on the commerce with the Indies in XVIth century, and on the encomienda have run in parallel without considering the historical relationship existing between both realities. From there, economic contradictions aroused within that relationship are pointed out and studied until the political crisis of 1541-1543.

KEYWORDS: Commerce, encomienda, consulado, leyes nuevas, XVI ${ }^{\mathrm{th}}$ century.

\section{Capital mercantil y encomienda: de espaldas en la historiografía}

Que el descubrimiento de las Indias por los europeos desencadenó una serie de efectos extraordinarios en la economía y la sociedad de Castilla - y de Europa-, es algo de sobra conocido pero, quizá y precisamente por ello, no analizado aún en todas sus dimensiones. Es claro que un artículo no es el lugar para abordar tan descomunal problemática pero puede serlo para considerar, aunque sea con alcance limitado, algunas de las consecuencias que se derivaron de dichos efectos sobre la política de la Monarquía con respecto a las mismas Indias en la primera mitad del siglo XVI, cuestión que, aunque ha sido objeto de estudio por muchos autores, pudiera aún ser considerada desde una nueva perspectiva. ${ }^{1}$ La tesis que pro-

1 Por ejemplo, Elliott, John: El Viejo Mundo y el Nuevo. 1492-1650, Alianza Ed., Madrid, 1990; Giménez Fernández, Manuel: El Plan Cisneros-Las Casas para la reformación de las Indias. Sevilla, Escuela de Estudios Hispano-Americanos (en adelante, EEHA), 1955, y Política inicial de Carlos I en Indias, EEHA, Sevilla, 1960; Vilar, Pierre, Oro y moneda en la Historia: 1450-1920, Eds. Ariel, Barcelona, 1969. 
pone este trabajo es que el desarrollo de las fuerzas económicas derivado directamente de la evolución que seguían la conquista y la colonización indianas, terminó por provocar fuertes contradicciones de intereses no sólo entre sectores sociales relacionados directamente con América, sino también en el seno del gobierno de la Monarquía, lo cual derivó en una profunda crisis política a comienzos de la década de 1540.

A muy grandes rasgos y englobando importantes complejidades y posiciones diferentes en el seno de los grandes bloques que se tomarán en cuenta, se pueden distinguir por un lado la Corona y su política, en representación de los intereses de la Monarquía con un proyecto que evolucionó de los Reyes Católicos a Carlos V - aunque en el interior de su propio gobierno había actitudes contradictorias con los objetivos del mismo-; el gran espacio financiero-mercantil con su principal base en Sevilla, que también presentaba posiciones encontradas a las que se aludirá más adelante; $y$, en tercer lugar, el gran bloque de los encomenderos indianos que, pese a su comunidad de intereses, también manifestaba grandes variaciones en su interior, como se indicará. La crisis derivada de la confrontación de objetivos de estos grandes bloques y que la historiografía sólo reconoce en una de sus facetas, tuvo un alcance mayor que el que hasta ahora se ha entendido y lo que se plantea en estas páginas es que, del desenlace de la misma y como parte de un único proceso, surgieron en años consecutivos las llamadas Leyes Nuevas (1542) y la creación del Consulado de Cargadores a Indias de Sevilla (1543), decisiones que estaban relacionadas entre sí por la coyuntura económica y que venían a redefinir en términos legales la relación de fuerzas existentes en el proceso colonial, en función de los intereses del proyecto imperial de la Monarquía. ${ }^{2}$

Para abordar esta perspectiva conviene comenzar por recordar que la Corona castellana o, dicho de otro modo, el gobierno de la Monarquía estaba sometido a profundas transformaciones económicas y sociales que afectaban no sólo a Castilla, sino a buena parte de Europa ya desde la segunda mitad del siglo XV. ${ }^{3}$ Con el capital comercial jugando uno de los papeles protagonistas, estaban en marcha importantes cambios en varias direcciones, una de las cuales consistía en la expansión y diversificación del uni-

2 Sólo Schäfer, Ernst: El Consejo Real y Supremo de las Indias, EEHA-CSIC, Sevilla, $1935-$ 1947, 2 vols. y después Hanke, Lewis: La lucha española por la justicia en la conquista de América. Aguilar, Madrid, 1959. Madrid, 1981

3 Miskimin, Harry: La economía europea en el Renacimiento tardío (1460.-1600), Cátedra, 
verso social de los sectores urbanos. ${ }^{4}$ En el caso castellano estos cambios repercutían en la composición de los intereses dominantes en la sociedad, y se traducían en nuevas alianzas pero también en conflictos de intereses que, además de en otros espacios, tenían su expresión en el ámbito del Estado, donde miembros de las nuevas oligarquías urbanas comenzaban a incorporarse a las estructuras administrativas cada vez más extensas de la monarquía junto a los representantes de las tradicionales clases dominantes castellanas - la nobleza, la alta jerarquía eclesiástica y las corporaciones militares y religiosas-.$^{5}$ Estas últimas estaban reforzando su alianza para seguir ejerciendo el poder en torno a una Monarquía que se movía en un esfuerzo centralizador, lo que no era óbice para que continuara existiendo un importante ámbito de jurisdicción señorial con su propio sistema fiscal, en paralelo al de la Corona, dando naturalmente lugar a roces y también a complicidades en el funcionamiento de la maquinaria del Estado. La importante fragmentación de jurisdicción que existió en Castilla a todo lo largo de la Edad Moderna dificulta poder hablar de Estado con propiedad en términos teóricos, pero la utilización del concepto y la expresión de Estado Moderno por la historiografía ha solucionado este obstáculo y, la investigación en esta línea en todo caso, con los matices necesarios, ha permitido la tesis de la existencia de un conglomerado de intereses de las clases dominantes en el control de la Monarquía. Y es precisamente en este marco donde encajan las observaciones que seguirán a continuación. ${ }^{6}$

Para iniciar la reflexión sobre el primero de los principales bloques de intereses económicos presentados arriba, conviene dejar claro que, en primer lugar, la condición "sine qua non" de los viajes castellanos a América a partir de 1492, y consiguientemente de su conquista y colonización, fue

4 Watts, Sheldon. J.: A Social History of Western Europe (1450-1720), Hutchinson University Library. Londres, 1984.

5 Domínguez Ortíz, Antonio: El Antiguo Régimen: Los Reyes Católicos y los Austrias, Alianza Ed., Madrid, 1973; González Alonso, Benjamín: Sobre el Estado y la Administración de la Corona de Castilla en el Antiguo Régimen, Siglo XXI, Madrid, 1981; MacKay, Angus: "Hacienda y sociedad en la Castilla bajomedieval", en Benassar, B. et al.: Estado, Hacienda y sociedad en la Historia de España, Universidad de Valladolid, Valladolid, 1989, págs. 45-78.

6 Anderson, Perry: El Estado absolutista, Siglo XXI, Madrid, 1979; Yun Casalilla, Bartolomé: La gestión del poder. Corona y economías aristocráticas en Castilla (siglos XVI-XVIII), Akal, Madrid, 2002. 
la existencia de una tradición de formación de capital mercantil en el sur de la Península Ibérica que estaba relacionada, en última instancia, con la evolución de la demografía y la economía europeas desde fines de la Edad Media. A dicha condición puede añadirse naturalmente la disponibilidad y el deseo de ciertos sectores sociales castellanos de emigrar a las nuevas tierras por diferentes motivos. Pero, de hecho, ninguno de ellos habría podido viajar a Indias ni haber visto cumplidas todas sus expectativas, cualesquiera que éstas fuesen, de haber faltado el capital necesario para los viajes, cuyos propietarios por otra parte, y como es ley en el funcionamiento del capital, exigían una tasa de ganancia para seguir operando. Para comprender el sentido último de la historia económica de la colonización española en Indias, especialmente en el siglo XVI, no se puede perder de vista la citada condición primigenia. El capital comercial que fue el motor inicial a la colonización de América dio lugar a una de las primeras e importantes etapas de la acumulación originaria del capital industrial, y a un proceso mucho más largo y tortuoso de inserción de las sociedades americanas al sistema capitalista internacional. ${ }^{7}$

Aunque desde el primer viaje de Colón la Corona castellana pretendió monopolizar el tráfico con América, su incapacidad inversora hizo que, a partir de 1498, reconociera esta condición y cediera el terreno para que fuese el capital mercantil privado el que básicamente se hiciera cargo de financiar el grueso de las expediciones de descubrimiento que iban a ponerse en marcha. ${ }^{8}$ Finalmente no puede ignorarse que el papel de la Corona terminó siendo el de promotora, coordinadora y beneficiaria también de los resultados de dichos viajes. La Monarquía castellana se encontraba en una etapa de consolidación impulsada por los Reyes Católicos y, lógicamente, quiso tener el control de la ocupación de los nuevos territorios que pasarían a formar parte de su patrimonio; por eso, además de fijar la jurisdicción sobre los mismos, emprendió la organización necesaria para poder percibir las rentas que le correspondieran de las diversas actividades económicas que se derivaran del comercio y su colonización.

Pero, siendo esto así, ya en el viaje inaugural de Colón la participación del capital privado fue fundamental y la posterior secuencia de viajes a las Indias sería inimaginable sin las inversiones de los cambistas y comer-

7 Marx, Carlos: El capital, FCE, México, 1946, vol I, cap. XXIV.

8 Algunas excepciones, en Mena, Carmen: "Lo privado y lo público en la exploración y conquista del Nuevo Mundo", en De la unión de Coronas al Imperio de Carlos V, Sociedad Estatal... de Felipe II y Carlos V, Madrid, 2000, vol. II, págs. 399-439. 
ciantes en Sevilla y otros puertos menores. ${ }^{9}$ Para el capital los nuevos territorios indianos se convirtieron muy pronto ante todo en mercados, donde la especulación y el riesgo - a partir de distancias, duración de los viajes, naufragios, capacidad negociadora, etc.- marcaban la tasa de beneficio que, lógicamente, exigía la existencia de un retorno que la hiciera posible. Y aquí es donde es imprescindible dirigir la mirada a los territorios transatlánticos, de donde debería proceder el contravalor de las inversiones capitalistas que hiciera posible su ganancia. ${ }^{10}$

Para presentar otro de los bloques de intereses apuntados arriba quizá conviene señalar que, procedente de las Indias y derivado precisamente de las características de su conquista, llegó uno de los más poderosos e imprevistos cambios económicos en la estructura social de la Monarquía a comienzos del XVI, cuyos efectos perduraron varias décadas. En el transcurso aproximado de medio siglo, de una manera gradual y creciente, surgió un nuevo sector en la sociedad castellana que, aunque físicamente se encontrase a miles de kilómetros de distancia de la Península, tuvo un potencial y unos efectos económicos extraordinarios, y modificó la estructura social y las relaciones entre sus miembros. Este sector fue el de los encomenderos de indios, esto es, el conjunto de personas - y en ocasiones corporaciones- que recibieron en Indias cuotas de familias de nativos para apropiarse del excedente económico que fuesen capaces de extraerles mediante una amplia diversidad de fórmulas, en función de las características de las economías de las mismas poblaciones indígenas.

Los componentes de lo que, sin mucho riesgo teórico, pudiera considerarse como una clase social - ya que muy pronto tuvieron conciencia de la especificidad de sus intereses y comenzaron a comportarse social y políticamente de forma acorde con ellos- $-{ }^{11}$ procedían de los sectores popula-

9 Francisco Pinelo, que invirtió 1.400 .000 mrs. para que, junto a los fondos de Luis de Santángel, se pudieran preparar los barcos del primer viaje colombino, como es bien sabido, era de origen genovés y un conocido mercader internacional en el Mediterráneo y en el Atlántico; fue jurado y fiel ejecutor de Sevilla, se le ha atribuido la propuesta inicial que dio origen a la Casa de la Contratación y se incorporó como uno de los primeros oficiales de la institución. Otte, Enrique: Sevilla y sus mercaderes a fines de la Edad Media, Universidad de Sevilla, Sevilla, 1996; Alberto Boscolo, "Il genovese Francesco Pinelli amico a Siviglia di Cristoforo Colombo", en Presencia italiana en Andalucía (siglos XIV-XVII), EEHA-CSIC, Sevilla, 1985, págs. 248-265; Schäfer, El Consejo Real..., vol. I, pág. 9; Pike, Ruth: Enterprise and Adventure. The Genoese in Sevilla and the Opening of the New World, Cornell University Press, Ithaca-New York, 1966, pág. 19.

10 Bernal, Antonio Miguel: La financiación de la Carrera de Indias (1492-1824), Fundación El Monte, Sevilla, 1992.

11 Sobre muestras tempranas del sentimiento de grupo de los encomenderos, ver Jiménez Fernández: Política inicial..., pág. 157. 
res tanto rurales como urbanos de la Península, tratándose a veces de personas que, pertenecientes a algunos de estos espacios sociales, se habían enrolado al servicio, militar o civil, del rey aprovechando el crecimiento del aparato institucional de la Monarquía desde fines del siglo XV y especialmente en la conquista de América. Es cierto que, en los primeros años de la conquista y ocupación de los nuevos territorios, algunos destacados personajes de la vida política española que nunca pisaron las Indias fueron titulares de encomiendas en el Caribe y gozaron de sus rentas, pero esta práctica fue suprimida hacia 1518 por considerarse incompatible. ${ }^{12}$ Sin embargo, se puede afirmar que, salvo estas excepciones, el colectivo de los encomenderos no se trataba de gente poderosa, ya propietaria en términos económicos que hubieran ampliado el espacio de su poder, sino de gente que tenía poco o nada en la Península y que, súbitamente, se vio convertida en "propietaria" de decenas, centenares o miles de campesinos que estaban a su servicio, con una productividad en muchos casos realmente extraordinaria, que incluía enormes cantidades de oro y de plata ente otros bienes. ${ }^{13}$ Es importante recalcar, en todo caso, que la formación del bloque de los encomenderos fue teniendo lugar a lo largo del proceso de conquista y ocupación de los sucesivos territorios indianos y que, en función de las características económicas y sociales de las poblaciones nativas conquistadas, la base y el poder económico de los encomenderos fue diferente, como se detallará más adelante, lo que influyó en sus relaciones con el ámbito del comercio y con la misma Corona.

$\mathrm{Y}$ es que, en efecto, para tratar del tercer bloque mencionado arriba, el de la Monarquía, hay que señalar que desde los ámbitos relacionados con las Indias en el gobierno metropolitano - Consejo de Castilla, Consejo de Indias, secretarios de los monarcas y otros- numerosos personajes trataron por diversas vías de controlar y beneficiarse de las grandes ventajas que comenzaban a proporcionar las Indias. Así, Lope de Conchillos, Juan Rodríguez de Fonseca, Francisco de los Cobos, fray García de Loaysa, Juan Suárez de Carvajal, etc., establecieron vínculos con conquistadores y encomenderos, colocaron a paniaguados en posiciones clave, obtuvieron rentas o beneficios económicos, y con ello consiguieron ampliar su cuota

12 Ver Acosta, Antonio: "La formación del Estado Moderno y la Hacienda colonial a comienzos del XVI", en De la unión de Coronas al Imperio de Carlos V, Sociedad Estatal... de Felipe II y Carlos V, Madrid, 2000, vol. II, págs. 463-496.

13 Pese a los claros fundamentos jurídicos de la encomienda, lo que explica las comillas, la realidad es que los encomenderos actuaban frecuentemente con sus indios y sus bienes como si fuesen verdaderos propietarios de los mismos. 
de poder personal. Muchos de los encomenderos, por su parte, a veces convertidos en autoridades en la colonia, actuaron en la misma dirección y aprovechando los efectos de las riquezas obtenidas de la población indígena sobre los políticos en la Península, vieron favorecidas sus posiciones.

$$
* * *
$$

Pues bien, lo interesante es que después de décadas de importantes avances en el conocimiento de estas tres parcelas de la historia colonial, la historiografía apenas las ha relacionado entre sí en conjunto, pese a que su interacción resulta fundamental, como parte de un único mecanismo, para comprender mejor el proceso de la colonización en Indias, la evolución del capital mercantil e incluso la de sectores específicos de la propia economía castellana. ${ }^{14}$ En efecto, por un lado, existe una larga, intensa y muy variada tradición (tanto desde el punto de vista teórico como metodológico) en el estudio del fenómeno comercial con Indias. Desde la perspectiva institucional en la que cabe mencionar a muchos autores, hasta la denominada historia serial, renovada con el paso de los años, pasando por los aspectos sociales del tráfico, y hasta la del más esencial análisis económico del fenómeno de la financiación y el crédito, la historia del comercio ha avanzado muchísimo y, aunque todavía hoy faltan parcelas por conocer, es bastante lo que se sabe acerca de lo fundamental de su evolución. ${ }^{15}$ Naturalmente, en esta prolífica corriente historiográfica la presencia del Estado, el papel de la Monarquía ha estado siempre presente pues las relaciones con el capital mercantil y con el comercio han sido necesariamente estrechísimas.

Mientras tanto, por otra parte, resulta difícil tratar de sintetizar en breves líneas la igualmente decisiva corriente historiográfica que, también durante décadas, ha venido avanzando en el conocimiento del fenómeno (nos resistimos a llamarla simplemente institución) de la encomienda y sus

14 Trabajos como el de Carlos Alberto González Sánchez: Dineros de ventura: la varia fortuna de la emigración a Indias (siglos XVI-XVII), Universidad de Sevilla, Sevilla, 1985, no invalidan la afirmación que aquí se hace.

15 Destacar a Haring, Clarence: Comercio y navegación entre España y las Indias en la época de los Habsburgos, FCE, México, 1979; Chaunu, H. et P.: Seville et l'Atlantique (1504-1650). SEVPEN, Paris, 1959, 11 vols.; Morineau, Michel: Incroyables gazettes et fabuleux métaux: le retour des trésors américaines d'après les gazettes honllandaises: XVIe-XVIIIe siècles, Cambridge University Press-Maison des Sciences de l'Homme, London-Paris, 1985; Pérez-Mallaína, Pablo E.: El hombre frente al mar: naufragios en la Carrera de Indias durante los siglos XVI y XVII, Universidad de Sevilla, Sevilla, 1996; Bernal, La financiación... 
alcances. Del mismo modo que en el caso del comercio, la encomienda ha sido tratada institucionalmente, también en sus efectos y como base para estudios demográficos, en sus consecuencias económicas, etc. ${ }^{16} \mathrm{Y}$ del mismo modo que en el caso del comercio, en este gran ámbito de la historia de las Indias que es la encomienda la Corona ha estado siempre presente, bien en sus decisiones tomadas desde la metrópoli, bien a partir de la actuación de las autoridades coloniales.

Sin embargo, lo que parece sorprendente es que ni los historiadores del comercio hayan tomado en consideración, puede decirse que nunca, la perspectiva de la encomienda en sus diferentes fases evolutivas, con sus distintas dimensiones económicas a lo largo del proceso de la conquista y de la colonización en el XVI al menos - porque sería esta centuria, a grandes rasgos, el período de tiempo para el que esta observación tuviera mayor importancia-; y, en sentido contrario, igualmente sorprende que quienes se han interesado por el mundo local americano y la encomienda, no hayan tenido en cuenta los flujos mercantiles y la evolución del capital, lo cual podría haber enriquecido los análisis de los primeros asentamientos en Indias en muchos casos. Parece como si ambas corrientes historiográficas hubiesen progresado de espaldas una a la otra.

Es evidente que la encomienda fue una fuente capaz de generar metales y otros bienes y, desde otra perspectiva, de controlar la mano de obra indígena y transformar su valor en el mercado a veces en importantes magnitudes. Este hecho tuvo una relación muy estrecha en muchos lugares y períodos temporales con la existencia de medios de pago en la colonia en mayores o menores cantidades para adquirir bienes europeos, con la demanda de los mismos, pero también como se verá con la posibilidad de entrar en negocios mercantiles, que originalmente estaban en manos de los comerciantes peninsulares. Pues bien, esta interrelación apenas si ha sido apreciada por la historiografía y las siguientes páginas sólo pretenden apuntar algunas de las líneas generales que siguió la evolución de ambos procesos.

16 Zavala, Silvio: La encomienda indiana, Junta de Ampliación de Estudios, Madrid, 1935; Gibson, Charles: Los aztecas bajo el dominio español. 1519-1810, Siglo XXI, México, 1967; Puente Brunke, José de la: Encomienda y encomenderos en el Perú. Estudio social y político de una institución colonial, Diputación Provincial, Sevilla, 1992; Trelles Aréstegui, Efraín. Lucas Martínez Vegazo: Funcionamiento de una encomienda peruana inicial, Pontificia Universidad Católica, Lima, 1982; Eugenio Martínez, M. Ángeles: Tributo y trabajo del indio en Nueva Granada (de Jiménez de Quesada a Sande), EEHA-CSIC, Sevilla, 1977; García Bernal, Cristina: Yucatán. Población y encomienda bajo los Austrias, EEHA-CSIC, Sevilla, 1979. 


\section{La penetración del capital mercantil en el Caribe}

Desde los primeros años de Colón el tráfico con Indias implicó un grado importante de riesgo, componente esencial en el que se basó el capital comercial para ampliar sus beneficios en relación con el tipo de operaciones en que actuaba hasta entonces en el Viejo Mundo: en el Mediterráneo, el Atlántico europeo o la costa occidental de África. ${ }^{17}$ Existía un riesgo físico que debían correr los maestres, los comerciantes u otros que fletaban un barco con destino a las Indias, sobre la base del cual el capital operaba por medio del crédito a interés; pero, además, las ganancias se justificaban precisamente sobre la base del riesgo —éste no ya físico, como el anterior, sino de inversión - que corría el dueño del capital que lo prestaba y que era mayor, como se ha dicho, en el caso del comercio con Indias que en el de otros destinos conocidos hasta entonces. ${ }^{18}$

El factor en el que se sustentaban, ante todo, las ganancias del capitalista era el trabajo de los maestres (si no eran propietarios de los barcos) y de los marineros. En realidad era el trabajo de estas personas el que permitía que los navíos viajaran de puerto a puerto, se entregasen las mercancías a un agente o factor, y subiese su precio. Naturalmente en la fijación del precio jugaban también los demás costes de la operación, entre los cuales se encontraba el interés que había que pagar al prestamista, la demanda de la mercancía en el lugar de destino; y por último, indudablemente la masa de medios de pago existente en el momento de la venta. Aunque sea elemental, es importante recordar esta base sobre la que funcionaba cualquier otro aspecto del comercio con Indias. Era a partir de este principio como se fueron tomando decisiones como las de modificar el tamaño y tonelaje de los barcos, el número y las condiciones de viaje de los tripulantes, en parte también el precio de las mercancías - que era factor y consecuencia de fenómenos económicos-, etc. En efecto, es claro que el precio de las mercancías en origen - que se había formado mediante mecanismos que aquí no hacen al caso - y la magnitud de las operaciones mercantiles tenían

17 Otte, Enrique: "El comercio exterior andaluz a fines de la Edad Media", en Actas del II Coloquio de Historia Medieval andaluza: Hacienda y comercio, Diputación Provincial, Sevilla, 1982; Aznar Vallejo, Eduardo: "Relaciones comerciales entre Andalucía y Canarias a fines del siglo XV y comienzos del siglo XVI", en Idem.; Rosa Olivera, L. de la: "Francisco de Riberol y la colonia genovesa en Canarias". Anuario de Estudios Atlánticos, vol 18, págs. 61-138, Madrid-Las Palmas, 1972; Ladero, Miguel Ángel: "Almojarifazgo sevillano y comercio exterior de Andalucía en el siglo XV”, en Anuario de Historia Económica y Social, n. ${ }^{\circ}$ 2, págs. 69-116, Madrid, 1969.

18 Este ha sido siempre el argumento usado por el capital. Ver Marx, El capital..., vol. I, cap. V. 
también influencia en el volumen y condiciones del crédito negociado. Todo ello constituye un cuadro económico, y más específicamente financiero y comercial, muy complejo del que apenas si se dispone todavía hoy de una visión general, de la que traeremos algunos datos al texto cuando sea oportuno. Desde luego resulta decisivo para los comentarios que se harán en las páginas que siguen tener claro que, al tratar de crédito y prestamistas, así como de comerciantes, la diversidad de personas y circunstancias que intervenían en los negocios era enorme y simplemente lo corto de este trabajo es lo que impide entrar en mayores precisiones, de cuya necesidad, en todo caso, somos perfectamente conscientes. ${ }^{19}$

$$
* * *
$$

Sobre la base de estas consideraciones, durante los primeros años de viajes a Indias, para que el capital mercantil de Sevilla mantuviera activos la inversión y el crédito que rentabilizara lo invertido, así como para satisfacer las rentas impuestas por la Corona sobre la producción y el comercio, era necesaria la existencia de una fuente de energía en Indias con la que obtener un producto que tuviera valor de cambio en el mercado. Esa energía fue la fuerza de trabajo de las personas que vivían en las islas y que, aplicada a la tierra - ambos medios de producción fueron apropiados por los conquistadores simplemente por el derecho derivado del uso de la violencia en la conquista-, se convirtieron en el combustible de la economía colonial. Si no se hubiera generado en las nuevas tierras descubiertas por los europeos un contravalor que rentabilizara el capital movilizado desde Sevilla, nunca hubieran tenido lugar futuras inversiones y los viajes a Indias probablemente no hubieran tenido continuidad. Dicho contravalor estuvo compuesto en menor medida por perlas, palo brasil y algún otro producto exótico, pero sobre todo por el oro antillano.

A.M. Bernal, el autor que ha abordado con mayor profundidad la perspectiva esencial del financiamiento y el crédito para conocer mejor el comercio con Indias, aun con la limitación de fuentes que tiene su trabajo, ofrece datos que permiten comprobar la importancia que tuvo rápidamente el negocio indiano, observando la evolución del monto medio anual de las

19 Un excelente resumen de las condiciones generales de los negocios lo ofrece Bernal, $\mathrm{La}$ financiación..., cap. IV. Ver también Pérez de Tudela, Juan: Las armadas de Indias y los orígenes de la política de colonización (1492-1505). Instituto Gonzalo Fernández de Oviedo. Madrid, 1956. 
escrituras de crédito marítimo en Sevilla — a partir de una muestra reducida en el primer período contemplado- de los años transcurridos entre 1466 y 1515. Los valores y los índices evolucionaron así:

\begin{tabular}{lcr} 
& $\begin{array}{c}\text { Importe medio anual } \\
\text { de escrituras (maravedis) }\end{array}$ & Índice \\
\hline $1466-1492$ & 3.027 & 100 \\
$1492-1506$ & 16.466 & 544 \\
$1507-1515$ & 37.961 & 1.254
\end{tabular}

Fuente: A. M. Bernal, La financiación de la Carrera de Indias..., pág. 197.

Ciertamente, el primer período de la comparación de este cuadro, que cubre 26 años, es de mucha mayor duración que el segundo, de sólo 6 , mientras que, por otra parte, el número de escrituras disponibles para aquél es mucho menor que en el segundo. Esto probablemente desvirtúa el resultado del cálculo de la evolución, que se traduce en un salto del índice 100 antes de 1492 al de 544 para los años inmediatamente posteriores a dicha fecha pero, en todo caso, a partir de los mismos datos utilizados por Bernal podemos calcular que en los primeros años de viajes a Indias un índice 100 calculado sobre un período menor de 26 años pudo fácilmente ascender a 300 , lo que sería un ritmo fuera del alcance de la evolución que estaba siguiendo el comercio marítimo dentro de Europa o con África. ${ }^{20}$

Lo que queda fuera de duda es que fue el incremento en la producción del oro, precisamente por medio del mecanismo de la encomienda, lo que hizo crecer el volumen del crédito en Sevilla y, con toda probabilidad, como se verá más adelante, las tasas de interés. Así, a partir de la utilización de mano de obra indígena americana en condiciones de cuasi-esclavitud o abiertamente esclava, se reproducía el capital comercial en esta primera etapa antillana de la ya mencionada acumulación originaria de capital.

20 A. M. Bernal maneja en su libro 26 escrituras (32 en pág. 97) entre 1472 y 1492. Si se tiene en cuenta la existencia de dos escrituras de $10.000 \mathrm{mrs}$. y se admite que pudiesen haber existido más de estas cantidades, podríamos elevar, como hipótesis, hasta una media de $7.000 \mathrm{mrs}$ (más del doble de la considerada por Bernal) la base del cálculo para los años 1466-1492 y, aún así, el salto de índices sería de 100 a 135 , lo que es un paso sin duda importantísimo. 
Bien se tratase de capitalistas, bien de simples inversores, bien de comerciantes, o de personas que reuniesen rasgos combinados de los perfiles anteriores, otro elemento esencial que estaba presente en el comercio de Indias, que es en realidad un rasgo casi consustancial con el capital privado, era la competencia. Pero si ni siquiera en el capitalismo moderno existe una competencia libre, mucho menos la había en el siglo XVI cuando este modo de producción no era ni con mucho el dominante. Tratando de los primeros quince años aproximadamente de los viajes al Nuevo Mundo, quienes se aventuraron a tratar con las Indias tenían que afrontar la competencia en varios frentes. El primero de éstos era el que los enfrentaba consigo mismos. Hay que recordar, aunque sea de modo breve, que en estos primeros años de la historia colonial la participación en el negocio mercantil era muy abierta y encontramos en él desde extranjeros - de los que había genoveses como el ya citado Francisco Pinelo y otros italianos pero también de otras nacionalidades-, a fuertes familias de comerciantes sevillanos, a burgaleses, de todos los cuales algunos estaban mejor posicionados que otros por sus relaciones económicas o políticas, pero también a maestres de naos, cómitres, artesanos de la ciudad o marineros. Las condiciones del comercio permitían poder participar en el mismo con inversiones relativamente pequeñas - como era el caso de los últimos citados-, junto a cifras ciertamente altísimas- que eran las que solía mover el primer tipo de comerciantes mencionados-, circunstancia que iría alterándose con el paso del tiempo, cuando llegara a crecer el volumen de las inversiones en el negocio tanto que provocase la virtual desaparición de los participantes de pequeña monta. Entre los competidores iniciales hay que mencionar también a la Corona, que intentó jugar el papel de agente monopólico del comercio en un caso de flagrante contradicción dado que no era capitalista. La competencia era pues grande en estos años.

Una vez que la Corona, en 1498, tras su intento de pugna con el capital privado por jugar como empresaria del comercio se reservó el papel de controladora y coordinadora del mismo, para cumplir con estas funciones se dotó en 1503 de la Casa de la Contratación, desde la que podía también extraer los impuestos que se establecieron sobre el tráfico. La Casa recibió competencias ampliadas en 1509 y 1511 , convirtiéndose en una especie de garante de la solvencia de créditos en el comercio, debiendo registrarse en la institución las garantías de los créditos que eran concedidos. Se diría que era ésta una función muy moderna, entendiéndose como lo que podría ser la búsqueda de un mercado financiero y mercantil transparente, pero esto 
estaba lejos de la realidad. Por el contrario, mientras que muchos maestres de naos y comerciantes tenían que registrar sus operaciones en la Casa de la Contratación, la Corona, coherente con su herencia medieval, otorgaba "mercedes" y concesiones graciosas a particulares para el comercio con Indias en lo que hoy podría llamarse competencia desleal con el capital privado. ${ }^{21}$ De manera que éste era otro terreno de la competencia, aunque fuera desigual, en el que se comenzaban a generar conflictos de intereses entre las dos partes en el caso americano.

Quizás por todo ello, pero también por la naturaleza invasiva del capital, que tiene una tendencia expansiva en su reproducción, que de todo hace mercancía y que ocupa y condiciona también los espacios políticos, se introdujo desde el comienzo del negocio en los propios órganos de la administración, como era la Casa de la Contratación. De manera que, de un lado, importantes comerciantes privados llegaron a ejercer como oficiales de la Casa, siendo el primero de ellos el ya mencionado Francisco Pinelo pero, por otra parte, oficiales que no eran originalmente comerciantes se involucraron en los negocios con Indias. Debido a esta mezcla de funciones entre actividades de interés estrictamente privado con la defensa de los intereses de la Corona, llegaron a producirse escandalosas contradicciones, con las consiguientes protestas del resto de la comunidad mercantil sevillana. No es de extrañar, por tanto, que algunas de las funciones más importantes que tenían encomendadas los oficiales de la Casa, como era el registro de las mercancías de los navíos, o la supervisión de las condiciones en que éstos tenían que hacer la travesía, se llevaran a cabo con frecuencia en condiciones escasamente rigurosas. ${ }^{22}$

Pero probablemente la gran novedad con respecto a lo que va expuesto, que en cierto modo era habitual aunque en menor magnitud en el comercio con África y con las Canarias, ${ }^{23}$ fue el desplazamiento del capital financiero sevillano a las Indias para intervenir en negocios no exclusivamente comerciales. Para comprender a cabalidad este proceso que justamente ponía en contacto a encomenderos con capitalistas privados procedentes de Sevilla, resulta imprescindible echar una mirada a los primeros, a los encomenderos antillanos que eran los que en principio parecía que debían estar

21 Archivo General de Indias (en adelante AGI), Indiferente General, 419, VII, 48 v. ; Colección de Documentos inéditos relativos... de América y Oceanía. Madrid, 1864. VII, págs. $423-4$.

22 Jacobs, Auke: "Funcionarios con las manos en la masa. La Casa de la Contratación durante el reinado de Carlos V", en Acosta, A. et al. (coords.): La Casa de la Contratación y la navegación entre España y las Indias, Universidad de Sevilla-CSIC, Sevilla, 2003, págs. 375-400.

23 Ladero, "Almojarifazgo..." 
llamados a poner en marcha las empresas de la economía colonial. Y lo primero que hay que destacar es la gran debilidad económica - lo que no es equivalente a escaso volumen de rentas-, de los encomenderos de las Antillas y de los de la mayor parte de la Tierra Firme colonizada en las dos primeras décadas, debilidad debida a y explicada por la también débil economía de los indígenas que tenían encomendados. Las sociedades autóctonas del Caribe eran de baja densidad demográfica y de una estructura social poco diversificada, disponían en su mayoría de una economía comunal en la que apenas si existía el campesinado y que generaba escasos excedentes agrarios. Todo ello repercutía en la economía encomendera que, salvo excepciones, dependía de las cuadrillas de indios, poco disciplinados para el trabajo entendido en términos europeos, para obtener el oro con el que pagaban a precios altísimos las mercancías que el comercio peninsular traía al Caribe. Todo ello condicionaba una relación extremadamente desigual, que permitió que los agresivos comerciantes sevillanos penetrasen en la economía caribeña y se hicieran cargo, gracias a sus altísimos beneficios, de negocios propios de la colonización. La debilidad de los encomenderos en el Caribe les restaba capacidad para emprender actividades productivas y los hacía depender de las importaciones, y en esa medida el capital mercantil ocupó un amplio espacio económico en la región.

Un caso perfectamente representativo de lo que sucedía es el de la familia de Bernaldo y Gerónimo Grimaldi, su sobrino, quienes se convirtieron a comienzos del XVI en unos de los más activos y prósperos empresarios del comercio en Indias. ${ }^{24}$ G. Grimaldi, con su criado Diego Caballero, se trasladaron pronto al Caribe donde se ocuparon de prósperos negocios que contribuyeron de forma notable a reproducir su capital y fortuna personal, el primero de los cuales fue la organización de armadas, en asociación con otros colonos, para capturar indios caribes esclavos tanto en las islas vecinas como en las costas de Venezuela. G. Grimaldi en 1514 fue nombrado "despachador de la armada" y D. Caballero tenía ya desde 1512 "la cuenta y razón de todas la armadas organizadas en la isla (de La Española)", y mantuvo un papel destacado en esta actividad hasta fines de la década por lo menos..$^{25}$ Las expediciones que se organizaban específica-

24 El caso ha sido bien documentado por Otte, Enrique: "Diego Caballero, funcionario de la Casa de la Contratación”, en A. Acosta et al. (coords.): La Casa de la Contratación..., págs. 315-339.

25 La fecha precisa del inicio de las armadas a cazar indios caribes no es conocida. Demetrio Ramos la fijaba en 1513, en Audacia, negocios y política en los viajes españoles de descubrimiento y rescate, Casa-Museo Colón, Valladolid, 1981, pág. 293. 
mente para cazar esclavos eran operaciones mercantiles, que exigían una inversión que ha llegado a evaluarse en torno a los 20.000 pesos procedentes de los recursos que se acumulaban en manos de comerciantes y de los colonos ricos. Se calculan en más de 80 las armadas que en la década de 1510 salieron de Santo Domingo para capturar indios esclavos, aunque esta cifra no refleja la totalidad del negocio porque muchos barcos salían a rescatar de forma ilegal sin dejar constancia oficial. La fuerza de trabajo obtenida de esta forma, es decir, esclavos en sentido estricto, ya tenía un coste y adquirió un precio de mercado que osciló entre 20 y 25 pesos, aunque a veces llegaron a subir hasta 40 .

El otro negocio en el que incursionó D. Caballero que, sin ser propiamente un colono llegó a "tener en mi poder y en mi compañía en esta Isla Española algunos caciques de aquellas Provincias", ${ }^{26}$ fue el de las pesquerías de perlas, en el que llegó a ocupar otro lugar también destacadísimo. ${ }^{27}$ Es difícil exagerar su protagonismo en esta actividad en la que, junto a sus hermanos, poseía la más importante compañía transatlántica de perlas con cuatro sedes: Cubagua, donde estaba la factoría, Santo Domingo, Sanlúcar de Barrameda y Sevilla, en cada una de las cuales había un agente de la empresa. ${ }^{28}$ La riqueza de Caballero y su influencia política a ambos lados del Atlántico fueron grandes, y no nos extenderemos en ello, llegando a ocupar cargos en la administración de la Hacienda Real en Santo Domingo.

Pero D. Caballero, aunque destacado, fue sólo uno de los empresarios que, con origen en el capital mercantil de Sevilla, ocuparon espacios importantes en la economía colonial. Otro que podría traerse como ejemplo era el Ldo. Gaspar de Espinosa, miembro de la conocida familia de banqueros y comerciantes burgaleses, con una riqueza e influencia en Tierra Firme también digna de resaltarse, en parte igualmente conseguida sobre la base de la captura de indios esclavos que eran vendidos en Santo Domingo, pero en otra parte muy importante y reveladora, gracias a su encomienda. En efecto, Espinosa llegó a organizar en 1515 una campaña con 200 soldados españoles, hacia el oeste de Santa María de la Antigua, en Tierra Firme, con unos resultados de hasta 1.500 castellanos de oro de botín para algunos de los miembros de la expedición y unos 2.000 indios cautivos que Espinosa vendió a Santo Domingo a 40 pesos por persona, en una coyuntura favorable

\footnotetext{
26 Otte, "Diego Caballero..." págs. 321-2.

27 Otte, Las perlas del Caribe: Nueva Cádiz de Cubagua, Fundación John Boulton, Caracas, 1977.

28 Otte, "Diego Caballero..."
} 
por la demanda que empezaba a crecer en la isla. Pero, por otro lado, Gaspar de Espinosa llegó a ser encomendero en Panamá donde, a comienzos de la década de 1520, algunos de los indios de sus encomiendas generaban una renta de hasta 3.000 pesos anuales. Espinosa tenía en realidad 500 indios de encomienda distribuidos entre 4 caciques y sólo el tributo extraído a 200 de ellos produjo un valor en 1522 de 1.953 pesos en el mercado y, en 1523, de 3.000 ps. No se conoce la composición del tributo que recibía Espinosa, pero a mediados de la década, otras encomiendas vecinas entregaban parte de su tributo en oro de minas y otra parte en maíz, ají, aves, cerdos, melones, sal y otras "granjerías" lo que indica que, aún antes de llegar a las sociedades de las altas culturas continentales, los españoles ya habían conseguido que los indios de algunas zonas de Tierra Firme produjesen especies europeas para ellos. Finalmente, es de sobra conocido es que G. de Espinosa llegaría a financiar la expedición de Francisco Pizarro para la conquista del Perú, de lo que se tratará más adelante. ${ }^{29}$

Lo que interesa retener de casos como los de Caballero y Espinosa es que ambos tuvieron ocasión de tener acceso a medios de producción, esto es, a indios a los que extraer el valor de su trabajo, aunque fuera por diferentes medios: a través de la figura jurídica de la encomienda o utilizándolos directamente como lo hacía Caballero en las pesquerías de perlas. En fases posteriores de la conquista las cosas serían distintas y el control de indios por parte de los comerciantes se volvería imposible.

Ahora bien, frente a estos ejemplos no se debe dejar de señalar, sin embargo, que aunque en una menor pero significativa medida, algunos encomenderos y otros colonos prósperos también llegaron a acumular suficientes recursos con los que emprender ellos también expediciones de conquista. Este sería el caso, por ejemplo, de Hernán Cortés, hombre adinerado y bien relacionado en las Antillas, quien en 1519 organizó en Cuba la armada con destino a México que daría comienzo a la conquista de Nueva España. Cortés aportó más de 5.000 castellanos y 7 navíos suyos y de sus amigos, en tanto Diego Velázquez colaboraba con casi 2.000 castellanos, 3 navíos y provisiones traídas, entre otros lugares, de Jamaica, lo que daba idea de la importante acumulación de recursos que se estaba produciendo en manos de muchos de los primeros colonos en Indias. ${ }^{30}$

29 Lohmann Villena, Guillermo: Les Espinosa. Une famille d'hommes d'affaires en Espagne et aux Indes à l'époque de la colonisation, SEVPEN, Paris, 1968, págs. 141 y 161.

30 Paso y Troncoso, Francisco de (recop.). Epistolario de Nueva España. 1505-1818, Antigua Librería de José Porrúa, México, 1939. 16 vols., I, pág. 44 
No obstante, hacia fines de la década de 1510 pareció iniciarse un ciclo relativamente adverso para el tráfico comercial y cabe preguntarse si también para el capital mercantil en su conjunto. En primer lugar, por aquellos años la crisis demográfica en las Antillas empezaba a generar otra subsiguiente en la producción de oro. ${ }^{31}$ La catástrofe demográfica indígena, que no conseguía ser subsanada con importación de indios caribes ni de esclavos africanos, tuvo una relación directa con la caída de las remesas de oro y probablemente la pérdida de beneficios para el capital. Si se toma la referencia de la curva de E. Hamilton de remesas de metales a la Península, a pesar de la falta de fiabilidad precisamente de la correspondiente al sector privado debido al fraude de las cantidades que se enviaban a España sin registrar, ${ }^{32}$ se observa justamente que a partir de 1517 el envío de oro desde las Antillas comenzó una seria caída: si en el quinquenio 1511-1515 habían llegado a la Península más de 1.195 .000 pesos, entre 1516 y 1520 la cantidad descendió a unos 993.000 , pero de 1521 a 1525 la cifra bajó a 134.170 pesos (de estas cantidades, sólo algo más de $25 \%$ correspondía a la Corona)..$^{33}$

El inicio del ciclo azucarero en Santo Domingo, que llegó a alcanzar una relativa importancia en el contexto de la economía colonial de la época, no fue ni de lejos una alternativa a la pérdida de peso que esta isla tenía sobre todo gracias a la producción de oro. ${ }^{34}$ Por otra parte, tampoco el inicio de la conquista de México desde 1519-1521 supuso por el momento una compensación al descenso de la importancia del Caribe en términos de producción de metales. A pesar de la riqueza de las nuevas tierras invadidas por Cortés, su rentabilidad en términos europeos, esto es, la gran oleada de metales que los conquistadores y los comerciantes esperaban no fue inmediata aunque, en realidad, la auténtica riqueza indígena era otra. $\mathrm{Ni}$ siquiera la expansión de la geografía que se continuaba ocupando sin cesar,

31 Moya Pons, Frank: Después de Colón. Trabajo, sociedad y política en la economía del oro, Alianza América, Madrid, 1986.

32 Esta falta de fiabilidad ya era señalada por Chaunu, Seville..., T. VII, pág. 697.

33 Hamilton, Earl: El tesoro americano y la revolución de los precios en España. 1501-1650, Ariel, Barcelona, 1975, pág. 34

34 Rodríguez Morel, Genaro: Economía y sociedad en La Española. Los orígenes de la industria azucarera durante el siglo XVI (en prensa). 
como sucedía por ejemplo en Centroamérica con Pedrarias Dávila, llegaba a suplir la caída del oro remitido a la Península, aunque aparentemente en principio se ampliaran las posibilidades de negocio, lo que no siempre resultaba fácil. ${ }^{35}$ Por añadidura buena parte de la década de los 20 estuvo marcada por el enfrentamiento de Castilla con Francia, que producía una creciente inseguridad en el comercio atlántico, sometido a un acoso por parte de corsarios franceses a ambos lados del Atlántico. ${ }^{36}$ Para mayor adversidad del complejo financiero-comercial en Sevilla, el ataque de corsarios franceses y berberiscos a los barcos que retornaban de Indias había hecho necesario implantar la avería para sostener las armadas, lo cual venía a sumarse a los costes de las operaciones, encareciéndolas, en años en que el retorno era precisamente menor. ${ }^{37}$

No se dispone de un registro de la evolución de las tasas de interés de los créditos para la época y, por otra parte, seguramente que esta variable no tenía en el siglo XVI un comportamiento tan institucionalizado como el que hoy conocemos en nuestro mundo financiero. De todas formas, el único y valioso intento que se ha hecho para penetrar en este terreno parece sugerir que en esta década de 1520 los tipos de interés más comunes, que habrían ascendido después de 1508, podían estar oscilando entre el $75 \%$ y el $80 \%$, sin que sea posible precisar una tendencia a corto plazo. ${ }^{38}$ Ahora bien, una vez más, lo que merece destacarse es que al estudiar un factor tan determinante para el tráfico comercial con las Indias se hayan tenido en cuenta las condiciones económicas en Europa - Chaunu no se interesó por el crédito ni el interés, pero sí por los precios de las mercancías en Castilla y Bernal se interesa por las condiciones de la economía local— pero no se tome en consideración la coyuntura americana como, por ejemplo, cuánta

35 Lohmann, Les Espinosa..., pág. 253. En Nicaragua, en la misma década de 1520, un factor comercial castellano que acompañaba a los conquistadores comunicaba que la ropa de Castilla que había recibido para venderla allí no valía nada porque los colonos usaban ropa de la tierra —es decir, tejidos indígenas - de la que "hay tanta... que sobra en todas partes".

36 Chaunu, Seville..., T. II, pág. 144.

37 Céspedes, Guillermo: "La avería en el comercio de Indias", en Anuario de Estudios Americanos, vol. II, Sevilla, 1945, págs. 515-698.

38 Bernal, La financiación..., págs. 182 y ss.: “...hasta 1508 el tipo de interés dominante parece que fuera el $100 \%$, que afectaría al $15 \%$ de los contratos; decrece en los años siguientes hasta remontar, suavemente, de nuevo, en los tramos finales de 1539-1542 a 1546-1551...".

Esto parece contradecirse con lo que expresa en la columna siguiente de la misma página: "A Indias, con frecuencia el $30 \%$ hasta $1517-19$, sobre todo los suscritos entre (sic) maestres y marinería. El 50\% comienza a destacar entre 1497 y 1506 y se erige un tipo preferente desde 1508, usual en las garantías de riesgo que tenían como garantía la nao... En su evolución cronológica el $60 \%$, sería el tipo de interés dominante hasta 1508 , mientras que el $75 \%$ y el $80 \%$ lo serían a partir de entonces.” 
plata se pensaba que hubiera, o había en realidad disponible, lo que también condicionaba el precio de las mercancías en destino y, a su vez, también debía formar parte de la especulación para establecer el precio del dinero.

La década de 1520 parece representar pues uno de los dientes de sierra que se iban a vivir en estos primeros años en la evolución del espacio comercial y financiero en el que, si acaso, aparecía un factor favorable a los intereses del crédito como era el crecimiento del riesgo con la ampliación del negocio comercial a tierras continentales. La conquista de Nueva España, que comenzaba a exigir un flujo de tráfico superior al de otros puntos de Tierra Firme hasta entonces, implicaba no tan sólo el acceso a un potencial metálico extraordinario, que pronto comenzaría a dar sus frutos - mayor disponibilidad de medios de pago y aumento de las ganancias al comercio-, sino una notablemente mayor duración de los viajes desde la Península hasta alcanzar el puerto base de la Nueva España, al fondo del Golfo de México, que era Veracruz. Como bien explicaron P. e H. Chaunu, el continente -el "auténtico" continente en términos coloniales frente a las Antillas y las "islas continentales" que eran las distintas zonas de Tierra Firme- estaba mucho más lejos de Europa de lo que estaban las islas. Entre las Antillas y Veracruz la verdadera distancia, en términos de días de navegación, significaba la cuarta e incluso la tercera parte de la distancia global del viaje desde la Península. Sólo desde Canarias a las Antillas el viaje tomaba de media unos 30 días, mientras que pasar de las islas a Veracruz era añadir 20 ó 30 días más de navegación a una ruta ya larga. Y los regresos pasando por La Habana no eran mucho más cortos y sí bastante arriesgados. ${ }^{39}$ Todo ello significaba una prima de riesgo que debía estarse trasladando a las operaciones crediticias a comerciantes con ventaja para los prestamistas y como reto para los comerciantes.

En medio de esta coyuntura adversa de los inicios de la década de los 20 para los intereses de los comerciantes y del capital mercantil de Sevilla, en 1523 se produjo otro revés importante y fue el primer secuestro por parte de la Monarquía de metales preciosos remitidos desde Indias para el sector privado. Las conocidas necesidades financieras de la Corona, que empezaba a generar su deuda, la movieron a incautarse de una cantidad aproximada a 300.000 ducados que, pese a ser compensada por juros, no

39 Chaunu, Seville..., T. VIII-1, pág. 687. 
dejaba de ser un duro golpe para el negocio del crédito y el comercio. El efecto de tal decisión, por inédita y por lo cuantioso de la cifra, fue impactante en los medios sevillanos y produjo quiebras, desconfianza y una reacción contraria entre comerciantes y cambistas.

En este complejo mundo de intereses cruzados que giraban en torno al sistema financiero, mercantil y fiscal, dos años después - aunque muy posiblemente antes- de este primer embargo de metales de particulares que se acaba de referir, se producía la primera toma de postura de una parte del sector financiero y comercial relacionado con Indias. En efecto, en 1525 , un grupo de hasta trece personas que se denominaban mercaderes se dirigía al monarca y le manifestaba que: “...con mucha insistencia han procurado que SM les diese la gobernación y jurisdicción de la Casa de Contratación por vía de Consulado, quitando a los oficiales que la sirven". Aparte de uno de ellos que se declaraba banquero además de mercader, entre los nombres de conocidos e importantes comerciantes de la lista llama la atención el de Luis Fernández de Alfaro, que había sido oficial asistente de contador de la Casa de la Contratación y que ahora también reclamaba la creación del Consulado. Pese a la fluidez de la situación, la coyuntural recesión en el volumen de negocios por las razones ya expuestas y el golpe recibido por el secuestro de las remesas hacían que el capital y los mercaderes tuvieran la decisión de dirigirse al rey para pedirle "con mucha insistencia" un espacio institucional autónomo para manejar el comercio americano ${ }^{40}$ Esto era muy importante y significa el comienzo, visible al menos, de una definición de intereses en el mundo mercantil sevillano de cara al comercio con Indias. Del texto se desprende, además, que la petición ya había tenido lugar antes de 1525 y, por otra parte, parece pertinente resaltar que esta primera petición de creación de un Consulado tenía lugar inmediatamente después del primer embargo de remesas de metales indianos con destino a particulares, lo que parece indicar una probable relación entre ambos hechos que nadie ha señalado hasta ahora.

Las presiones fiscales de la Corona, que seguirían ocasionando problemas similares pocos años más tarde, eran sin duda un factor muy influyente en el mundo comercial con las Indias, pero no menos importantes eran las circunstancias en el terreno de las propias colonias, que eran el destino de este comercio, donde las cosas estaban cambiando a pasos agigantados.

40 AGI, Justicia, 943; Bernal, La financiación..., págs. 123 y ss. 


\section{Predominio de la encomienda sobre el capital mercantil en Nueva España}

Las sociedades indígenas que descubrió Cortés al penetrar en el continente a partir de 1519 no tenían mucho que ver en términos económicos con las que estaba habituado a tratar en las Antillas y en Tierra Firme. De entrada eran muchísimo más densas demográficamente, su agricultura era también más productiva sin comparación con la de las islas, se trataba de sociedades muy diversificadas, de una fuerte base campesina y con una capacidad productiva artesanal extraordinaria. La estructuración social muy acentuada daba lugar, en el caso de la Triple Alianza, al pago de grandes cantidades de tributos a las autoridades, generados por sociedades conquistadas con una mano de obra muy disciplinada en el trabajo, otra gran diferencia con las Antillas. No dejan de sorprender en este sentido las cantidades que se calcula que ingresaban anualmente a Tenochtitlan al margen de la propia producción en la ciudad, que dan una idea de la productividad de aquellas economías campesinas y que se resumen en: cerca de 7.000 toneladas de maíz, más de 4.000 toneladas de frijol y otras 8.000 más de diversos vegetales como el huauhtli o amaranto. A esto se añadían 21 toneladas de cacao, 36 toneladas de chile seco, 1.500 cantarillos de miel y más de 2.500 de maguey. La tributación anual en vestuario no era menor, de modo que las mantas sumaban más de dos millones de unidades y las de henequén casi 300.000 . Además se entregaban unas 240.000 naguas y otros tantos huipiles, 144.000 maxtlatl, junto con 4.400 fardos de algodón al natural. La cuantía del trabajo requerido para la siembra, cosecha y elaboración de todos estos textiles es digna de ser resaltada. Pero, para hacerse una idea completa de la tributación anual de las sociedades conquistadas, habría que agregar muchos otros productos, algunos de gran valor, que iban desde armas y rodelas, plumas diversas, leña, papel, jícaras, cañas de hacer flechas, cal, petates, aparejos para llevar carga, grana, cochinilla, copal, ámbar, conchas de mar, objetos de cobre, piedras preciosas y hasta oro en polvo y en tejuelos. ${ }^{41}$

En suma, a los ojos de los conquistadores, pese a los graves incidentes bélicos que vivieron, se abrió rápidamente la posibilidad de organizar otro tipo distinto de economía colonial a la que habían dejado atrás. De entrada, el apoyo que recibió Cortés en todos los terrenos de determinadas naciones

41 Molins i Fábrega, N.: El Códice Mendocino y la economía de Tenochtitlán, Eds. Libro-Mex. México, 1956, págs. 28 y ss. 
indígenas, como los tlaxcaltecas, fue decisivo en la conquista y sin dicha ayuda probablemente habría terminado en fracaso. Después, inmediatamente y pese a la oposición de la Corona tras la pésima experiencia de la encomienda para la población indígena en las Antillas, el conquistador comenzó a repartir indios entre su hueste en calidad de "depósito", una modalidad sólo jurídicamente distinta a la encomienda, pero que conduciría a ella merced al poder económico y político de los encomenderos, como acabó sucediendo.

La década de 1520 fue particularmente grave para las poblaciones indígenas que estaban siendo conquistadas en Nueva España, debido a las enfermedades y al trato al trato que les proporcionaban conquistadores, encomenderos y colonos en general, produciéndose una alta mortalidad, así como una abundante esclavización, aunque no es objeto de este trabajo extenderse en ello. Pero lo que se derivó de la incontrolada explotación de los indígenas fue que los colonos pronto iniciaron el camino hacia una economía claramente más autónoma que la que existía en las tierras del Caribe. La capacidad agrícola y de trabajo, en general, de los indios de Nueva España permitió a los colonos imponerles cultivos como el trigo y otras especies peninsulares, así como la cría de animales domésticos, con lo que comenzaron a cubrir una cuota de necesidades superior a la que podían cubrir anteriormente en las islas. No es que los colonos no necesitaran vino, aceite y otros productos europeos pero, ya antes de 1530, Cabildos y autoridades de Nueva España habían establecido algunas tasas a la venta de mercancías procedentes de la metrópoli de manera que, probablemente a causa de protestas de comerciantes, la Corona tuvo que emitir una real provisión prohibiendo tasaciones que se consideraban arbitrarias declarando que "los mercaderes pudiesen vender en Nueva España las mercaderías que llevasen en ella, a los precios que pudiesen, sin que los justicias les presiesen tasa alguna". ${ }^{42}$ No se conoce sobre qué productos en concreto se habían establecido dichas tasas, pero es claro que los colonos de Nueva España trataban de adoptar una posición proteccionista en algunos artículos, lo que da idea de que la economía encomendera temprana en las nuevas regiones del continente daba signos de una, aunque mínima, autonomía eso sí, sobre la base de la explotación de las poblaciones nativas. El capital comercial y el comercio, que estaba experimentando la citada recesión en los años 1520 y sufriendo en Sevilla la presión de la Corona, como se ha visto en 1523 , comenzaba a percibir ahora en

42 Chaunu, Seville..., T. II, pág. 206. 
Nueva España síntomas de un posicionamiento contrapuesto a sus intereses por parte de los encomenderos, con lo que seguía creciendo la definición de bloques de intereses encontrados en el sistema colonial.

De todas formas, en el segundo quinquenio de la década de los años veinte el tráfico con las Indias comenzó a recuperarse de nuevo, y parte de esa recuperación era debida al comercio con Veracruz que comenzaba a dar salida a los metales de las primeras minas mexicanas como Taxco, Sultepec o Tlalpujahua, con lo que crecía la masa de medios de pago para las mercancías procedentes de España y debían subir los beneficios empresariales. Además, en 1529 se había firmado la Paz de Cambrai entre España y Francia y se avecinaban algunos años de mayor tranquilidad en el mar y de disminución de costes en el comercio, en la medida en que no sería necesario emplear tantos recursos para la protección de los barcos en el Atlántico.

Ahora bien, si en las Antillas y áreas de Tierra Firme el capital comercial de origen peninsular había sido capaz de penetrar en la economía colonial participando en diferentes operaciones de conquista y en la organización de compañías para conseguir mano de obra esclava suplementaria a la de los indios encomendados, en Nueva España, donde las correspondientes acciones eran de mucha mayor envergadura, el capital prácticamente estuvo ausente a la hora de su organización, bastándose casi exclusivamente los colonos con los recursos extraídos sobre el terreno a las poblaciones indígenas locales ya conquistadas. Era un abastecimiento sobre la base de la población campesina autóctona.

Una de las muchas operaciones que pueden citarse a título de ejemplo en la que el capital peninsular ya no estaba presente es la expedición organizada por Hernán Cortés para conquistar la Huasteca en la que, además de 450 soldados españoles, movilizó un ejército aliado compuesto probablemente por más de 50.000 guerreros indígenas ya que, según el cronista Ixtlilxóchitl, sólo de aculhuas participaron más de 40.000 efectivos. Otro caso un poco más tardío fue el de la operación organizada por Nuño de Guzmán, presidente de la Primera Audiencia, para conquistar el territorio de los teúles chichimecas. En su salida hacia Michoacán, Guzmán encabezaba a unos 400 españoles de a pie y de a caballo, cerca de 12.000 indios aliados mexicanos y tlaxcaltecas, más 12 piezas de artillería. ${ }^{43}$ Natural-

43 Assadourian, Carlos Sempat: "Esclavos, plata y dioses en la conquista de los teúles chichimecas”, en Menegus, Margarita (coord.): Dos décadas de investigación en historia económica comparada en América Latina, El Colegio de México y otros, México, 1999, págs. 63-65. 
mente el abastecimiento y el armamento de todas estas tropas indígenas era proporcionado por las comunidades étnicas de procedencia, sin coste ni necesidad de crédito para los españoles.

Y es que el nivel que podía alcanzar el excedente económico extraído por un encomendero a sus indios en Nueva España era altísimo y, al igual que en el caso de tributo a Tenochtitlan, reflejaba la capacidad productiva de las comunidades. También a título de ejemplo se puede citar el caso del encomendero Miguel Díaz de Aux — que había sido oficial real en Puerto Rico antes de pasar a México- quien tuvo encomiendas en Tempoal (Pánuco) y en Meztitlán, antes de ser encomendero de Tepatlaostoc, en Texcoco. ${ }^{44}$ De esta última encomienda, sólo en un año, 1527-1528, envió a sus minas de oro que distaban 30 leguas de la encomienda a 1.200 tamemes, o indios de carga, junto con diez indias y varios principales del pueblo, los cuales llevaron 3.700 cargas de maíz, gallinas, etc. Además, recibió de los indios de su encomienda 40 tejuelos de oro, 12 cargas de ropa, 80.000 granos de ajo (sic, ¿por ají?), 200 panes de sal, 80 fanegas de frijoles, 800 de maíz molido, 800 de harina de maíz, 20 cargas de bizcocho, "300 tamemes de gallinas" y 60 cargas de pinole. ${ }^{45}$

Estaba claro que no en términos cuantitativos en cuanto al tráfico marítimo — que hacia 1530 se estaba recuperando-, pero sí en cuanto a presencia en la economía colonial, el papel del capital mercantil con base en Sevilla había disminuido en comparación con el protagonismo que todavía tenía en el Caribe, y en Nueva España no había figuras como G. de Espinosa o D. Caballero. Los comerciantes de Sevilla, con algunos de sus agentes y empresarios en las Antillas y Tierra Firme, continuaban controlando el tráfico y el negocio de mercancías en el Atlántico, pero estaban ausentes de la producción de bienes y de su circulación en el interior de Nueva España. E incluso en relación con el crédito en la nueva economía encomendera, aunque era posible ver a algunos comerciantes sevillanos en la colonia, iba a estar asegurado no sólo por la producción indígena, sino también por otros recursos que veremos a continuación. Se puede decir que se estaba definiendo una nueva relación de fuerzas entre el capital mercantil y los nuevos encomenderos en la que aquél estaba encontrando un techo, un límite a la expansión y a la posibilidad de negocios en el interior de los

\footnotetext{
44 Gerhard, Peter: A Guide to Historical Geography of New Spain, At Cambridge University, Cambridge, 1972, págs. 183, 216 y 312.

45 Ruiz Medrano, Ethelia: Gobierno y sociedad en Nueva España: Segunda Audiencia y Antonio de Mendoza, El Colegio de Michoacán, Zamora, 1991, pág. 73.
} 
nuevos territorios coloniales. Esta limitación venía definida por el hecho de que en las nuevas conquistas del continente los comerciantes no habían conseguido acceder al control de los medios de producción, esto es, los indios y la tierra, que ahora eran monopolizados por los encomenderos, al contrario de lo que había sucedido antes en el Caribe. Esto era lo que marcaba la diferencia.

\section{Agudización de contradicciones entre encomenderos, capital y Corona}

A fines de 1533 llegaban a España las primeras e impactantes noticias de la extraordinaria conquista que se había iniciado en Perú, para cuyo comienzo precisamente había sido necesario el financiamiento facilitado por Gaspar de Espinosa. ${ }^{46}$ El flujo general del comercio con Indias se recuperaba, aunque a ritmo lento y desigual, gracias al crecimiento del tráfico con Nueva España y, en menor medida, con las incursiones que la conquista realizaba hacia múltiples direcciones del Nuevo Mundo: Venezuela, Nueva Granada, Florida, etc.; y entonces, Nombre de Dios como destino, con su proyección al Perú, vino a modificar radicalmente el equilibrio de fuerzas existentes hasta ese momento en los negocios comerciales. El arranque no estuvo exento de altibajos pero, sobre todo en los primeros años, la cantidad de metales puestos en el mercado fue fantástica. Hay que recordar que la fundición de oro y plata que siguió al rescate de Atahualpa en Cajamarca, ascendió a casi un millón y medio de pesos, de los que correspondieron a la Corona más de 220.000 en concepto de quintos, pero la que tuvo lugar en Cuzco tras la conquista de la ciudad fue todavía mayor y supuso más de 1.900 .000 pesos, con lo que los quintos del rey fueron aún superiores. Eran cantidades nunca conocidas. Recurriendo de nuevo a los datos de Hamilton sólo a título de referencia, frente a los 1.038.437 pesos del total de las remesas percibidas en España en el quinquenio 1526-1530 - lo que ya era un incremento importante en relación con los años 1521-1525-, entre 1531 y 1535 se recibieron 1.650 .230 ps. (el 26,2\% de la Corona), y entre 1536 y $1540,3.937 .892$ (el $34 \%$ correspondiente al rey), es decir que en diez años se había incrementado en un 379\% el total de los metales recibidos de América, lo que en gran medida tenía su origen en Perú. ${ }^{77}$

46 Lohmann, Les Espinosa...

47 Hamilton, El tesoro..., pág. 34. 
Por otra parte, las poblaciones indígenas encontradas por los españoles en los Andes eran, aunque con características muy singulares y diferentes a las de las sociedades novohispanas, tan ricas y productivas como aquéllas, también sobre la base de un campesinado extraordinariamente eficiente en la organización y el uso de los recursos naturales, y con una capacidad de tributación, fundamentalmente en trabajo, extraordinaria. A partir de ella los españoles pudieron extraer cantidades enormes de trabajo, bienes y metales, así como hacerles adaptar a suelo andino, como en Nueva España, cultivos y animales europeos.

La imagen causada por la riqueza del Perú comenzó a ejercer un atractivo y un estímulo superior a todo lo conocido en términos de inversión capitalista, considerando por añadidura las dificultades - y el riesgo suplementario, con lo que ello significaba de encarecimiento de los precios de las mercancías- que implicaba el paso de Panamá, la navegación desde allí a Lima y sobre todo el retorno, con una duración desproporcionada de la navegación. Sin embargo, pese a que representantes y agentes de intereses comerciales de la Península comenzaron a trasladarse a Perú y llegaron en algunos casos a realizar excelentes negocios a veces al amparo y con la ayuda del poder político, sus líneas fundamentales de actuación económica se parecieron mucho a las que ya se han señalado en el caso de la Nueva España, en el sentido de que se hicieron fuertes en el espacio del comercio marítimo pero apenas penetraron a la circulación de mercancías por el interior de la colonia - un espacio dominado por los encomenderos incluso en el caso de las mercancías venidas de España - y casi nada funcionaron en otro tipo de actividades empresariales productivas.

Algunos de los miembros de las familias comerciales con apellidos más conocidos en Sevilla llegaron a Lima acompañando a autoridades políticas, como sucedió con el juez pesquisidor Cristóbal Vaca de Castro, quien viajó a Perú para investigar los múltiples problemas políticos y — casi más preocupante para la Corona - fiscales que estaban produciendo allí los enfrentamientos armados entre distintas facciones de conquistadores. $\mathrm{Y}$ en efecto, comerciantes como Cristóbal de Burgos, Fernando de Sepúlveda, Ruy Díaz de Gibraleón, Luis Suárez, Diego de Illescas y otros estaban actuando en Lima a fines de la década de 1530 y comienzos de los años 1540 facilitando algunos créditos y negociando con España. ${ }^{48}$ Poco más tar-

48 Ver AGI, Escribanía de Cámara, 498; Levillier, Roberto: Gobernantes del Perú. Cartas y papeles. Siglo XVI, Biblioteca del Congreso Argentino, Madrid, 1921-26, vol. I, pág. 77. 
de, aunque en fecha desconocida, haría su aparición en Lima el que sería después gran comerciante Juan Antonio Corzo, yerno de Antonio Corzo "el Viejo", que ya desde 1525 comerciaba con Santo Domingo. ${ }^{49}$

Sin embargo, a pesar de su presencia tampoco pudieron entrar en operaciones comerciales que años atrás controlaban en el Caribe y que ahora eran objeto de control exclusivo de parte de los colonos que se enriquecían gracias a las fantásticas riquezas con valor de cambio en el mercado proporcionadas por las poblaciones conquistadas, la primera de las cuales eran los propios seres humanos. Ya se han visto las armadas en busca de caribes o las expediciones de Espinosa. Un poco después, ya en Pánuco, en los primeros años de la conquista de Nueva España, se había explotado de nuevo el recurso humano herrando y vendiendo como esclavos a las islas del Caribe quizá a más de 10.000 indígenas, en un negocio al que acudieron a obtener beneficios empresariales "los comerciantes y tratantes que por estas islas andan". ${ }^{50}$ Esta fue una vasta operación controlada por colonos que eran los vendedores, en la que los comerciantes sólo fueron transportistas.

No obstante, con ocasión de la conquista del Perú tuvo lugar otra gran operación de venta masiva de esclavos, mucho mayor que la anterior, exportando indígenas de diferentes grupos étnicos de la costa occidental de América Central, desde Nicaragua a los Andes, por la vía marítima del Pacífico en cifras que algunos autores elevan a centenares de miles. Entre 1528 y fines de la década de 1540, Centroamérica, con Nicaragua como principal núcleo, fue una de las bases fundamentales del comercio de esclavos indígenas que comenzó bajo el gobierno de Pedrarias Dávila y que en la década de 1530 constituyó el negocio más lucrativo de los españoles en la región. Una media de 10.000 esclavos al año entre 1532 y 1542 con destino a los Andes se considera una cifra prudente de aquel comercio y, entre 1536 y 1540, cuando las exportaciones de indios estaban en su momento más alto, se calcula que había unos 20 barcos transportando esclavos entre Realejo, Nicoya, Panamá y Perú, con una frecuencia de hasta seis veces al

49 Un Paolo Vicencio Corzo luchó en el bando de Gonzalo Pizarro en la tercera de las "guerras civiles" del Perú. Por otra parte, en la segunda mitad del XVI, cuando se produjera la explosión de la plata de Potosí y la economía colonial, incluyendo el papel de la encomienda, hubiese cambiado en relación a la primera mitad del siglo, Juan Antonio Corzo llegaría a ser un poderosísimo comerciante, con presencia en diferentes lugares de Indias, que intervino en el mercado interior y hasta en la vida política de la colonia. Vila Vilar, Enriqueta: "Los Corzos: un 'clan' en la colonización de América. Apuntes para su historia”, Anuario de Estudios Americanos, vol. XLII, Sevilla, 1985, págs. 1-42, y Los Corzo y los Mañara: tipos y arquetipos del mercader con América, EEHA-CSIC, Sevilla, 1991. 50 Assadourian, "Esclavos..." pág. 64. 
año en los viajes a Panamá y unas o dos veces con destino a Perú. Y todo esto estaba también en manos exclusivas de los colonos y comerciantes locales.

Los comerciantes vinculados a Sevilla ya no ocupaban algunos de los espacios económicos de que disfrutaron en el Caribe, pero el negocio comercial con Lima era extraordinario y además no estaban pagando el almojarifazgo de las mercancías que transportaban de Panamá al Perú, lo que les suponía una cuota de ganancia proporcionalmente superior a la que obtenían en el tráfico atlántico. Por otra parte, los créditos que ofrecían en la colonia no eran tan importantes en aquellos años, ya que los propios colonos, enriquecidos por la conquista, eran capaces de facilitar crédito. Y tan importante como esto, o más, eran los fondos procedentes de otra fuente de recursos que no estaba prevista para los particulares, pero de la que se aprovecharon profusamente los conquistadores y los colonos en las primeras décadas de la colonización, que era la Real Hacienda. ${ }^{51}$ Algunos de los que utilizaban con largueza los fondos del erario real eran sus propios oficiales, quienes además eran encomenderos, y algunos de ellos, combinando esta diversidad de fuentes de ingresos, llegaron a organizar prósperas empresas en la colonia entre las que había compañías comerciales que competían con los mercaderes de origen sevillano.

Pues bien, en pleno auge de la fase expansiva de los metales indianos volvieron a surgirle problemas al sector comercial. De un lado, en 1535 empeoraron otra vez las condiciones de navegación al endurecerse las relaciones políticas con Francia y también con los berberiscos, lo que obligó de nuevo a organizar armadas para proteger los barcos españoles, con el consiguiente encarecimiento de los fletes por la avería. La situación general se hacía más difícil aún porque, entre otras adversidades, también estaba la de la escasez de navíos y personal cualificado para la navegación. Pero, por otro lado, el problema más grave fue que aquel mismo año la Corona volvió a embargar los fondos procedentes de Indias para los particulares por primera vez (después del secuestro de 1523 ya mencionado) en una serie de hasta tres incautaciones en 1535,1536 y 1538 . La mayor cantidad ocupada tuvo lugar en la primera ocasión, en que se incautaron hasta 800.000 ducados de oro y plata procedentes del Perú. En los años siguientes las cantidades fueron menores, en torno a 150.000 ducados, pero en

51 Acosta, Antonio: "Estado, clases y Real Hacienda en los inicios de la conquista del Perú", en Revista de Indias (en prensa). 
conjunto la actuación fue demoledora sobre el comercio. De poco valía que se emitieran juros al $3 \%$ en compensación a sus dueños puesto que, dadas las condiciones financieras de la Monarquía, éstos rápidamente se devaluaban. Como se ha escrito, aquel hecho era más grave y producía mucho más desasosiego e incertidumbre en los negocios que cualquier impuesto que la Corona cobrase a los comerciantes en la Carrera. ${ }^{52}$

Los años de 1537 y 1538 fueron de gran presión en los ambientes financieros y mercantiles y, aunque no conocemos detalles, es más que probable que en aquellos momentos se reanudaran las presiones de los comerciantes sobre la corte y la Corona para conseguir de una vez la autorización para crear el Consulado - como había sucedido en 1523-1525-, con el objeto de que los grandes cargadores, al manejar directamente los aspectos estratégicos del comercio, se resarcieran de alguna forma de las dificultades - simples descensos de beneficios en muchos casos- que estaban experimentando.

Por su parte, la Corona, que decidía intervenir las remesas de Indias para los particulares, dejaba de ingresar importantes cantidades de sus rentas en la Real Hacienda en la colonia en gran medida por una pésima gestión por parte de sus propios servidores en la administración colonial y sus oficiales reales. ${ }^{53}$ Sólo en el caso del Perú, entre los períodos de los gobiernos de Francisco Pizarro y Cristóbal Vaca de Castro, casi medio millón de pesos de la Hacienda Real fueron utilizados por las autoridades y los encomenderos en sus propias luchas y en reprimir la rebelión indígena de 1536, en lugar de haber utilizado para ello sus propios recursos como encomenderos que eran, puesto que se comprometían a mantener la tierra al recibir las encomiendas.

Este comportamiento de las autoridades en la colonia era tutelado a título particular desde el propio Consejo de Indias por varios de sus miembros, así como por el secretario Francisco de los Cobos, quienes tenían intereses personales directos en la colonia y respaldaban la labor de gobernantes y encomenderos. Así, cuando en 1539 Bartolomé de las Casas pudo denunciar al emperador las connivencias existentes en el propio gobierno metropolitano con la mala gestión indiana, que tenía repercusiones (1) en la Real Hacienda, (2) en el trato a los indios, y (3) indirectamente en el comercio, no es de extrañar que Carlos $\mathrm{V}$ decidiera abrir la crisis política.

52 Carande, Ramón: Carlos Vy sus banqueros, Sociedad de Estudios y Publicaciones, Madrid, 1967, T. III, págs. 169 y ss.; Chaunu, Seville..., Tomo II, pág. 256.

53 Acosta, "Estado..." 


\section{La crisis y el desenlace}

Se trataba de una coyuntura especialmente grave que, más allá de los problemas que estaban a la vista, afectaba a largo plazo a los ingresos de la Hacienda procedentes del negocio indiano y esto, a su vez, a las finanzas de la Monarquía cuyo futuro, no sólo su presente, estaba ya suficientemente hipotecado. El nudo gordiano del problema parecía ser la consistente posición de fuerza económica de los encomenderos quienes, con el control casi monopólico de los medios de producción, limitaban el crecimiento del mercado indiano y, en relación con ello, cerraban la posibilidad de que muchos colonos que continuaban emigrando a América iniciaran negocios empresariales. Sin indios, esto no era posible. Para agravar este panorama, la mortalidad indígena era galopante y, como ya se sabía desde los primeros años del Caribe por palabras de Alonso Zuazo:

“...porque el bien de todos estos reinos... esta en que esten poblados de indios, e faltando estos, falta todo; faltan las rentas de S.A. que no habrá quien saque oro; falta la población destas partes e granjerías dellas, e finalmente de tierras tan abundosas e fertilisimas convertirse-han en aposento de animales...". ${ }^{54}$

De forma que parecía urgente atender a este problema. Pero además, por vía directa o indirecta, una de las derivaciones al menos en parte del tapón que constituían los encomenderos en las Indias, era la situación de los comerciantes y el capital que también reclamaban una posición más ventajosa para garantizar sus márgenes de beneficios en el comercio indiano. Ahora bien, lo más próximo para el emperador era la corte y, quizá por ello, Carlos V inició el tratamiento de la crisis con una visita al Consejo de Indias entre 1540 y 1541 que dio como consecuencia la inhabilitación y sanción a varios de sus miembros — algunos de los cuales, no obstante, "se recuperaron" poco después y continuaron ostentando altos cargos en el poder de la Monarquía— ${ }^{55}$; acto seguido continuó con la promulgación de las llamadas Leyes Nuevas, en 1542; y finalmente terminó en 1543 con la autorización para la creación del Consulado de Cargadores en Sevilla.

Las Leyes Nuevas comenzaban con una especie de disculpa del emperador por no haberse podido ocupar antes de los asuntos de Indias y, además de cuestiones relacionadas con la administración de justicia y el

54 AGI, Patronato, 170, R. 21

55 Martínez Millán, José (ed.): Instituciones y élites de poder en la Monarquía hispana durante el siglo XVI, Eds. de la Universidad Autónoma de Madrid, Madrid, 1952, pág. 30 
gobierno, abordaban la incompatibilidad de las autoridades indianas, incluyendo los oficiales de Hacienda, para poder ser encomenderos pero sobre todo - y lo que era todavía más importante-, quebraban el control directo de los encomenderos sobre el trabajo y la producción indígena estableciendo que el tributo que recibiesen aquéllos fuese tasado y entregado periódicamente al beneficiario. Esto era crucial porque abría la puerta a que, mediante otros mecanismos que se articularían después —el más importante, el repartimiento-, otras personas pudieran tener acceso a indios y, con ello, creciera y se diversificara la economía colonial a costa, eso sí, de la integridad de las comunidades indígenas.

Por su parte, los cargadores a Indias veían satisfecha su aspiración de contar con una institución desde la que controlar tres aspectos cruciales que les daban mucho poder, y por lo tanto mejores posiciones económicas, en el sistema mercantil: a) la negociación con la Corona sobre la cuestión de los registros e inspecciones de las cargas a efectos fiscales; b) disponer de total competencia a efectos de quiebras mercantiles y financieras; y c) tomar el control del crédito con la jurisdicción sobre las licencias de cambios y préstamos marítimos. ${ }^{56}$ Otras cuestiones muy importantes también, como la administración de la escasez en el mercado indiano, a base de establecer el sistema de flotas, vendrían poco después proporcionando otra dimensión, y otros problemas también, a la Carrera.

Parece claro que los problemas, y su correspondiente solución, en cada una de estas tres parcelas permitirían una explicación en clave local. Es decir, había razones estrictamente de gestión del negocio financiero y mercantil en Sevilla para poder explicar el por qué de la presión de los grandes cargadores para conseguir su propio espacio de poder con un Consulado. Por otra parte, había suficientes motivos de quejas contra los encomenderos por sus actuaciones en las Indias (los mal llamados abusos, como si la misma conquista no fuese ya un abuso) como para poder explicar que se reaccionara contra ellos por parte de la Corona. Y, por último, había también muchas denuncias sobre las corruptelas de miembros del gobierno metropolitano en la gestión indiana. Pero sería de ciegos no percibir que, en última instancia, se trataba de elementos de una misma maquinaria relacionados entre sí, y que las decisiones adoptadas afectaban directamente a una modificación en la relación de fuerzas entre dichos elementos, y en principio - o eso parecía - a un reforzamiento de la posi-

56 Bernal, La financiación... págs. 116-7. 
ción del capital mercantil, al tiempo que a una derrota de los encomenderos, todo lo cual daría pie a la aparición de nuevas formas de producción en la economía indiana.

Permítasenos de todas formas añadir como apostilla y en letra pequeña que, pese a todo, a medio plazo podría apreciarse pronto que ni todos los encomenderos fueron totalmente derrotados, ni el capital mercantil triunfó completamente pues sus limitaciones se harían evidentes en el siglo XVII y, como se adelantó, muchos políticos en la metrópoli continuaron "flotando" en las esferas del poder. Pero ésta es otra historia.

Recibido el 1 de marzo de 2005 Aceptado el 20 de julio de 2005 